\title{
KUI KÕIK ON VÄGA HALVASTI
}

\section{Kasulik ja kasutu klassikaline filoloogia}

Alexander Lenard (Lénárd Sándor, 1910-1972) oli oma põlvkonna üks haritumaid ungarlasi. Olles õppinud arstiks, tegutses ta ka kirjaniku, luuletaja, tõlkija ja maalikunstnikuna. Pärast Esimese maailmasõja lõppu elas Lenard koos oma perekonnaga Balkani poolsaarel, kus kolis pidevalt ühest kohast teise. Aastail 1928-1932 õnnestus tal veidi pikemalt peatuda Viinis ja omandada arstidiplom. Pärast Austria anneksiooni põgenes Lenard Itaaliasse, kus läks sügavale põranda alla. See tähendas Lenardi puhul, et ta viibis suurema osa ajast Vatikani raamatukogus ja tegeles seal renessansiaegsete uurimustega neerudest ning hormoonravi ajalooga antiikajal. Kui Teine maailmasõda lõppes, pakuti talle professorikohta Ungaris, millest ta loobus, sest ei näinud endas korralikku kommunistimaterjali. ${ }^{1}$ Selle asemel võttis ta 1952. aastal üheotsapileti Brasiiliasse, kus töötas algul pliikaevanduses meditsiiniõena ja hiljem apteekrina, sest tema Austrias omandatud arstidiplomit ei tunnistatud, ning teenis lisa keeletundide ja tõlkimisega. Lenard valdas kahtteist keelt. Juba pliikaevanduses töötades hakkas ta tõlkima ladina keelde A. A. Milne'i kuulsat lasteraamatut „Karupoeg Puhh”. Tõlkimisele kulus Lenardil seitse aastat. Pärast seda lasi ta São Paulos oma viimaste peesode eest trükkida tõlkest 100 eksemplari, mille saatis laiali kirjastustele üle maailma. $^{2}$

${ }^{1}$ A. Lenard, The Valley of the Latin Bear. New York: E. P. Dutton \& Co., Inc., 1965. http://mek.oszk.hu/02700/02764/html/

${ }^{2}$ E. McDowell, 'Winnie Ille Pu' nearly XXV years later. - The New York Times 18. XI 1984, http://www.nytimes.com/1984/11/18/
Niimoodi käituda - pühenduda sõja ajal meditsiiniajaloole, pärast sõda tõlkida lasteraamatut surnud keelde ja kirjastada see oma viimase raha eest - pole sugugi pragmaatiline, kui viibitakse majanduslikult ja poliitiliselt keerulises olukorras nagu Lenard.

J. D. Salingeri teismekirjanduse üleilmsesse kullafondi kuuluvas jutustuses „Franny ja Zooey” loeb Zooey oma venna saadetud vanu kirju, kus meenutatakse, kuidas Zooey oli nooremana saanud õnnetust armastusest üle sellega, et katsus tõlkida Mundaka Upanišadi klassikalisse kreeka keelde. ${ }^{3}$ Sellest pole onnetu armastuse puhul mingit kasu. See ei too armastatut tagasi, mis oleks ainus positiivne programm niisuguses olukorras.

Sulev Keeduse mängufilmis „Georgica” (1998) tõlgib endine misjonär Jakub vanarooma poeedi Vergiliuse õpetlikku heksameetris poeemi "Georgica" ladina keelest suahiili keelde, et kunagi jõuaksid „rõõm, rahu ja rikkus” ka masaide õuele. On täiesti selge, et raamat masaideni eales ei jõua. Jakub saab nimelt filmi lõpupoole surma ja tõlge jääb lõpetamata. Sellist saatust Jakub ilmselt ette näha ei oska, kuid ometi on talle kindlasti teada, et Aafrikasse ta raamatut niikuinii ei vii: elab ta ju Nõukogude Liidus raudse eesriide taga. Vähe sellest, ta on saadetud sisepagulusse, ainsaks elanikuks nimetule Eesti rannikusaarele, kus tegeleb õppepolügoonile heidetud pommide taba-

books/winnie-ille-pu-nearly-xxv-years-later. html

${ }^{3}$ J. D. S a ling er, Kuristik rukkis. Novellid. Puusepad, tõstke kõrgele sarikad. Franny ja Zooey. Tallinn: Eesti Raamat, 1973. 
muste ülestähendamise ja selle teabe staapi edastamise tähtsa tööga. Jakubi misjonärielu on seljataga ja reisimised reisitud. Lisaks tuleks veel meenutada, et Vergiliuse „Georgica”, kuigi kirjanduslikult oivaline, on põllumehe käsiraamatuna masaidele praktiliselt kasutu: „[N]agu ütleb meie Vergilius, kes piinlikult täpsele õpetusele eelistas ilusat ütlemisviisi, sest tema soov oli mitte põllumehi õpetada, vaid lugejat lõbustada."

1976. aastal ilmus Lennart Meri raamat „Hõbevalge”, mis mõjus vastumürgina rahvuslikule meeleheitele. Teoses esitatud tõlgendused on teaduslikult kaheldavad ning raamatu omaaegne vastuvõtt oli vastuoluline, ometi on „Hõbevalge" müüdina kaljukindel. Meri ei kummutanud seal nõukogude ajalookäsitlust, õõnestanud nõukogude võimu ega kutsunud üles selle vastu võitlema. Selle asemel vaatas ta sellest üle ja selle taha, kus asub täiesti kasutu: Pytheas, Strabon, Sitsiilia Diodoros, Vanem ja Noorem Plinius, Pomponius Mela, al-Idrisi ja teised.

Üsna sarnaselt leidis legendaarne klassikaline filoloog Jaan Unt (19472012) võimaluse ahistavais ühiskondlikes oludes jääda iseendaks, avastades 17-aastaselt enda jaoks filosoofkeiser Marcus Aureliuse ja liikudes sealt edasi juba kõige muu kasutu juurde. ${ }^{5}$

Need on näited selle kohta, mida tehakse siis, kui ükski n-ö kasulik lahendus ei anna rahuldavat tulemust, aga ometi on vaja jääda inimeseks ja säilitada mingi identiteet. Marju Lepajõe kirjutab, et suutlikkus lugeda vanakreeka keeles Homerost ja loetut mõista on inimese kui inimese privileeg. ${ }^{6}$ Kindlasti on inimese kui inimese privileege veel teisigi, kuid vanakreeka keelt

${ }^{4}$ L. A. Sen eca, Moraalikirjad Luciliusele, LXXXVI 15. Tlk I. Vene.Tartu: Ilmamaa, 2008 , lk 301.

${ }^{5}$ P. Olesk, Ärge kartke tuupimist. Postimees 10. XI 2007. http://www.postimees.ee/1725227/aerge-kartke-tuupimist

${ }^{6}$ M. Lepajõe, Roomlaste taltsutamine. (Eesti mõttelugu 102.) Tartu: Ilmamaa, 2011, lk 445 . osata on kahtlemata üks neist. Kasulik on oma olemuselt pigem universaalne. Seda saab kindlaks teha matemaatilise optimeerimisega, kõrvutades erinevaid andmeid või pannes kirja plusse ja miinuseid. Täiesti kasutu on seevastu kultuuriti erinev. Meil moodustab ühe suure osa sellest antiik. Meeldigu see meile või mitte, kuid midagi paremat ka praegu võtta ei ole.

Kuulsamaid tänapäeva renessansiuurijaid, itaallane Nuccio Ordine väidab raamatus „Kasutu kasulikkus”, et osa teadmisi on eesmärk iseeneses, nad on kõigile kättesaadavad ja omakasupüüdmatud, vabad otstarbekuse survest. $^{7}$ Antiikkirjandus on kõigile kättesaadav ja omakasupüüdmatu juba selles mõttes, et seda ei piira autoriõigused, peale selle ei saa ta olla vähemalt Euroopa kultuuriruumis ühegi võimu monopol. Mis puutub otstarbekusse, siis teatud olukordades on tõesti mõistlik sellest lähtuda, kuid nagu ülal sai viidatud, pole haruldased ka juhtumid, kui kasulik enam ei „tööta”. Sel juhul pöördutakse täiesti kasutu poole.

Kui asjad on hästi, võib meeliskleda selle üle, milleks üldse see kasutu. Praegu on elu päris hea. Ometi tuleb ka täna mõelda sellele, mis saab, kui kõik on väga halvasti: majanduslikult, poliitiliselt ja/või isiklikus elus. Varem või hiljem juhtub see nii või teisiti ja siis muutub täiesti kasutu asendamatuks. Kas me oskame siis tõlkida mõnd lasteraamatut ladina keelde või, vastupidi, tõlkida vanakreeka keelest järjest kõik Platoni ja Aristotelese kirjutised meie hiljasündinud väikesesse kultuurkeelde, mille kõnelejate arv pidevalt väheneb? Kui me ka ise ei oska, piisab vahel teadmisestki, et kusagil on keegi, kes seda oskab ja teeb. Ja et ta jõuab välja koolitada õpilase, kes töö üle võtab ja pakub tulevikuski edasi täiesti kasutut ühiskondlikku teenust.

NEEME NÄRIPÄ

${ }^{7}$ N. Ordin e, L'Utilité de l'inutile. Paris: Les Belles Lettres, 2014, lk X. 